\section{Occupational hazards correlates of ocular disorders in Ghanaian fisheries}

\author{
Samuel Kyei, ${ }^{1}$ Andrew Owusu-Ansah, ${ }^{1,2}$ \\ Samuel Bert Boadi-Kusi, ${ }^{1}$ \\ Dennis Nii Abbey, ${ }^{1}$ \\ Emmanuel Kwasi Abu'
}

'Department of Optometry, School of Allied Health Sciences, College of Health and Allied Sciences, University of Cape Coast, Cape Coast, Ghana; ${ }^{2}$ Department of Ophthalmology, The Second Xiangya Hospital of Central South University, Changsha, Hunan, China

\section{Abstract}

The study examined the ocular health of agricultural workers in the fisheries sub sector with the aim of establishing a possible correlation between the work place hazards and their ocular health. A multi-stage random sampling (involving 683 subjects, 358 fishmongers and 325 fishers) was employed. Ocular hazards encountered at the work place included seawater, sand or dust, heat, sunrays and smoke. Exposure to these hazards were found to be associated with ocular irritation $(\mathrm{P}<0.001)$, tearing $(\mathrm{P}<0.001)$, red eye $(\mathrm{P}<0.001)$, gritty sensation $(\mathrm{P}<0.001)$, blurred distant vision $(\mathrm{P}=0.001)$ and blurred near vision $(\mathrm{P}=0.001)$. The development of pterygium was associated with the exposure to sunrays $(\mathrm{P}=0.042)$ and heat $(\mathrm{P}=0.001)$ among fishmongers. Further analysis using multivariate logistic regression indicated exposure to heat as the most important predictive factor for pterygium $(\mathrm{OR}=1.951, \mathrm{P}=0.003)$. Exposure to seawater was found to be associated with the development of cataract $(\mathrm{P}=0.022)$ among fishermen/fishers. Cataract among fishmongers was rather associated with exposure to heat $(\mathrm{P}=0.005)$, sunrays $(\mathrm{P}=0.035)$ and sand/dust $(\mathrm{P}=0.002)$. Exposure to work place hazards is associated with ocular disorders in the fishing industry of Ghana.

\section{Introduction}

Comparative statistical records on fatalities in fisheries around the globe put fishing as one of the most dangerous jobs ahead of driving, fire fighting, policing and others who ply their work on land and remains history's most dangerous occupation. ${ }^{1}$ Globally, it is estimated that 24,000 fatalities occur in the fisheries industry annually. In coastal countries of West Africa, artisanal canoe fatality rates range from 300 to 1000 per 100,000 fishermen. In Nordic countries where there is evidence of best practices regarding accident prevention, survival training, search and rescue services, fatality rates still persist between 90 and 150 per 100,000 people. This underscores the likelihood of under estimation of fisheries fatalities in countries where there are no data. ${ }^{2,3}$

Reports of non fatal injuries are rather too common in spite of evidence of under reporting attributable to paucity of and unsatisfactory documentation from several countries of the world. ${ }^{4,5}$ Apart from the vast evidence of fatalities and injuries among workers in the fisheries industry, ocular injuries, most of which are sight threatening, have been specifically cited..$^{6-8}$ These injuries are commonly associated with the hazardous working environment in most fisheries which include the use of fishing hooks, lures, weights, biofuels and excessive reflection of extraneous sun rays. ${ }^{6,7}$ The specificity and diversity of hazards, depending considerably on geographical-climate and cultural factors, make the differentiation of problems and solutions important in different zones of fishing.

Ghana has a marine coastline of $550 \mathrm{~km}$, which extends from Aflao in the East to Half Assini in the West; the fishing industry serves as a source of livelihood for some $10 \%$ of Ghanaians. ${ }^{9}$ The sector has seen a decline in its contribution to the Nation's gross domestic product (GDP) over the past decade. It is estimated to contribute some $1.5 \%$ of the Agriculture GDP (GSS, 2013 Budget). ${ }^{10}$ Most fish consumed in Ghana comes from the marine fishing industry and it remains the favorite and cheapest source of animal protein with about 75 per cent of total annual production being consumed domestically. ${ }^{11,12}$ An average of 500,000 fishermen, fish processors, traders and boat builders are employed in the fishing industry. ${ }^{13} \mathrm{~A}$ canoe census conducted for the marine fisheries estimated the number of artisanal fishermen at $124,000 .{ }^{14}$ Artisanal fishing involves the use of dugout canoes propelled by outboard motors. Ghana's coastline stretches along the Atlantic Ocean providing rich grounds for artisanal marine fishing. ${ }^{3}$ The Central Region has long been noted as a fishing hub. ${ }^{15}$ Historical records trace the subsistence of the fishing industry in the Central Region as early as $1471,{ }^{15}$ operating in household-based entities and utilizing small vessels. Notwithstanding the importance of the fishing industry to the overall economy and nutritional needs of the country, players within the industry are exposed to several workplace hazards
Correspondence: Samuel Kyei, Department of Optometry, School of Allied Health Sciences, College of Health and Allied Sciences, University of Cape Coast, Cape Coast, Ghana.

Tel: +233243309718.

E-mail: skyei@ucc.edu.gh; samdollar2@yahoo.com

Key words: Cataract; Artisanal fishing; Fishmongers; Atlantic Ocean; Pterygium.

Contributions: SK conceived the idea and designed the study. AOA and SBB were also involved in the design of the study. DNA and EKA wrote the protocol, managed the literature searches and collected data. SK and DNA wrote the first draft of the manuscript. SK, DNA, SBB and $A O A$ managed the analyses and interpretation of the data. SK, AOA, EKA critically revised the content. All authors read and approved the final manuscript.

Conflict of interest: the authors declare no potential conflict of interest.

Acknowledgements: the authors are grateful to Mrs Esther Kyei, Mrs Alice Abu, Mrs Mary BoadiKusi and Mrs Jennifer Owusu-Ansah for their immense support and encouragement.

Received for publication: 9 August 2015.

Revision received: 29 May 2016.

Accepted for publication: 19 October 2016.

This work is licensed under a Creative Commons Attribution 4.0 License (by-nc 4.0).

(C) Copyright S. Kyei et al., 2016

Licensee PAGEPress, Italy

Healthcare in Low-resource Settings 2016; 4:5482 doi:10.4081/hls.2016.5482

with long term consequence for their health especially their eye health. Recent data from the International Labor Organization (ILO) and the World Health Organization (WHO) indicate that overall occupational accident and disease rates are slowly declining in most industrialized countries, ${ }^{16}$ but are on level or increasing in developing countries.

Generally, there are several hazards associated with the fishing industry but those that directly pose threats to the eye as outlined in the literature include dust/sand, plants, chemicals, decomposing leaves, micro-organisms in the fishing environment, smoke, radiations and heat, equipments and machines with sharp and pointed edges. ${ }^{17}$ It has been noted that there is a dearth of information on the potential effect of such exposures on the eyes of workers of the fishing industry mainly fishermen and fishmongers. We therefore sought to evaluate the correlations between these hazards and ocular disorder in the fishing industry of Ghana. 


\section{Materials and Methods}

\section{Study area}

The Central Region of Ghana has the widest continental shelf and the longest coastline of $150 \mathrm{~km}$ spanning eight (8) coastal districts ${ }^{18}$ (Figure 1). There are 43 coastal towns and villages from Gomoa Nyanyano in the East to Kafodzidzi in the West with a total of 103 landing sites. The two main types of marine fishing are; artisanal or Canoe Fisheries and inshore Fisheries. There are 46,513 artisanal fishermen working with 4675 canoes as against 1500 inshore fishermen operating over 100 inshore motor fishing vessels. The fishermen in the region dock about $36 \%$ of the Nation's fish production. ${ }^{19}$ These include some exportable species of marketable value such as: lobsters, squids and octopuses, shrimps, soles, sea breams, mackerels, groupers, skipjack tunas, yellow fin tunas, round and flat sardinellas and sailfish. ${ }^{19}$

\section{Sampling technique}

Multi-stage random sampling was employed. Four out of the eight coastal districts were randomly selected of which a fishing town or villages each was also randomly selected (Figure 1). In each of the four fishing towns or villages, two landing sites were randomly selected. A register of fishers /fishermen and fishmongers for each chosen landing site was then obtained from the chief fishermen and the queen fishmongers as per their records. A total of 683 (involving 358 fishmongers and 325 fishers) people within these four major communities were sampled. The minimum sample size for the survey was determined as quoted by Glenn using the formula developed by Cochran (1963). ${ }^{20}$ The minimum sample size computed was 374 . However, the sample size was adjusted to 683 to include 358 fishmongers and 325 fishers to reduce the incidence of reporting false positive responses.

\section{Subject selection/data collection procedure}

The subjects were systematically selected (every nth person) based on the number of participants needed for that area for interview using a pretested interview-based questionnaire and subsequent routine ophthalmic examination (external and internal eye exams) by four experienced optometrists, ODs.

\section{Inclusion/exclusion criteria}

The study participants included fishers/fishermen and fishmongers who had been engaged in the fishing industry not less than 3 years and were aged 18 years and older at the time of the study. All fishers/fishermen or fishmongers who had other part time engage- ments outside of the fishing industry were excluded.

\section{Data analysis procedure}

Data collected was analyzed using SPSS version 19 (Statistical Package for Social Sciences) and reported as frequency tables, percentage tables, bar charts and cross tabulation. Goodness of fit-test was calculated to compare the frequency levels between fishmongers and fishermen. Chi-square model was performed to measure the association between categorical variables. Multivariate logistic regression was also conducted to measure the predictive ability of the independent variable (hazards) to the dependent variables (prevalent ocular diseases and symptoms). The alpha level was set at $\mathrm{P}=0.05$, thus association existed between categorical variables when $\mathrm{P} \leq 0.05$.

\section{Ethical consideration}

The research was done according to the Helsinki Declaration on Research Regarding Human Subjects. A detailed rationale for the study was given to respondents, after which respondents signed a consent form or verbal consent depending on their educational background. Confidentiality was ensured and a forum was organized to educate participants on basic safety measures regarding their workplace. Those with ocular disorders were treated and some referred to eye clinics for further attention.

\section{Results}

\section{Socio-demographic characteristics}

A total of 683 participants comprising 325 fishers and 358 fishmongers were interviewed and examined in this study. All the participating fishers/fishermen were males while 354 females and 4 males were fishmongers. Majority of the fishmongers $(181,51.0 \%)$ and fishermen $(158,48.8 \%)$ were in the age range of 36-59 years (adult). Those aged between 18 and 35 (Youth) were 102 (28.7\%) for fishmongers and 126 (38.9\%) for fishermen and those aged 60 and older were $72(20.3 \%)$ for fishmongers and 40 (12.3\%) for fishermen. Goodness of fit test showed no significant difference $(\mathrm{P}=0.236)$ between the total participants of fishers/fishermen and fishmongers. The results indicated that the majority of the fishermen and fishmongers had no form of formal education and only one person each among the fishermen and fishmongers had had tertiary education. The most frequent income range for both fishermen and fishmongers was GH 1000-1999 (US\$350-699) and the least number of the respondents had an income range of $\mathrm{GH} \quad 4000-4999$ (US\$ 1400 1749) (Table 1).

\section{Ocular hazards}

There were 623 and 717 responses (due to multiple responses) to ocular hazards identified at the workplace by fishermen and fishmongers respectively. Sun rays was the main ocular hazard reported among the fishermen (299, 36.8\%). The fishmongers on the other hand, reported smoke 357 (49.8\%) as the main

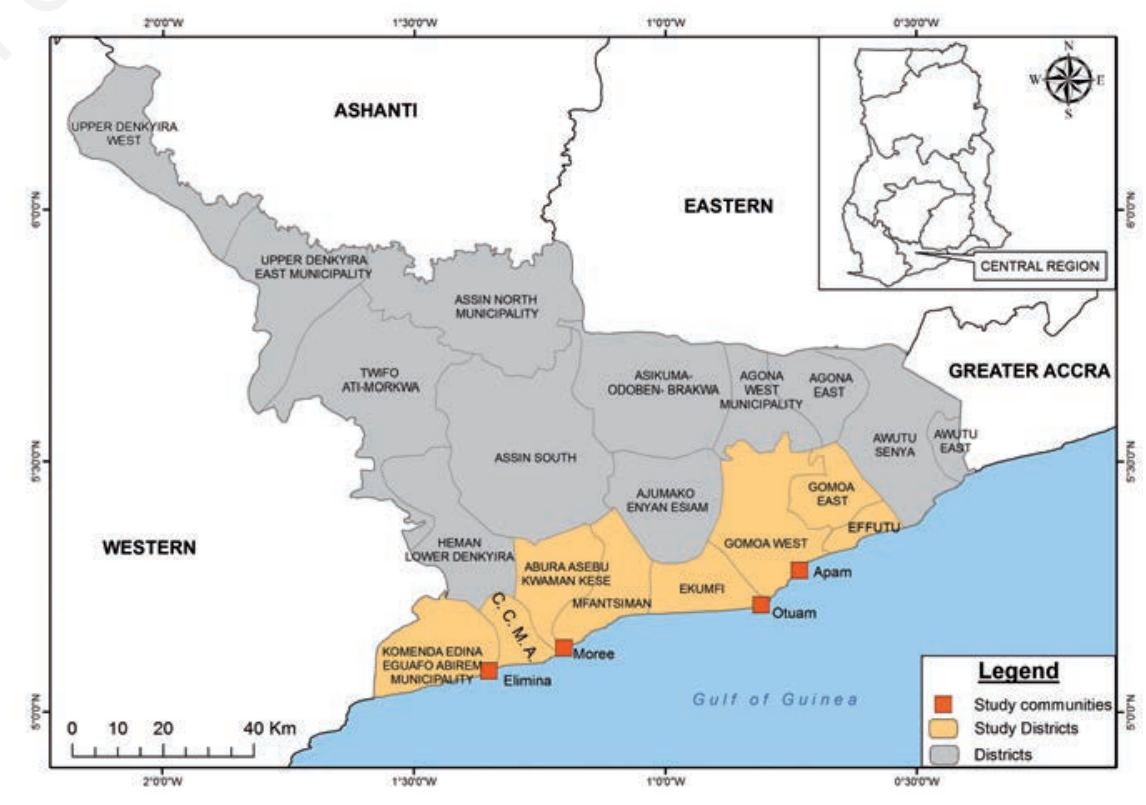

Figure 1. A map of the Central Region showing the study districts and communities. 
ocular hazard (Table 2).

\section{Ocular symptoms after exposure to hazards}

Ocular symptoms after exposure to hazards during smoking of fish by fishmongers indicated 1126 responses (due to multiple responses) with irritation of the eyes being the highest and redness being the least. The most prevalent symptom among fishmongers included photophobia, 222 (62.2\%), 217 (60.8\%) complaints of burry distance vision, 201 (56.3\%) complaints of tearing, 154 (43.1\%) complaints of ocular pain, 143 (51.3\%) complaints of burning sensation. Ocular symptoms after exposure to hazards during fishing by fishermen indicated 997 responses with blurry distance vision being the highest $273(72.70 \%)$. The others were irritation 138 (61.1\%), gritty sensations 232 (71.2\%), ocular pains 162 (49.7\%), photophobia 211 (64.7\%) and tearing 225 (78.2\%) (Table 3).

Players within the fishing industry were more prone to suffer ocular irritation $(\mathrm{P}<0.001)$ than burning sensation. There was significant association between ocular irritation and some identified workplace hazards such as smoke $(\mathrm{P}=0.001)$, heat $(\mathrm{P}=0.002)$, dust/sand $(\mathrm{P}=0.047)$ and seawater $(\mathrm{P}=0.016)$. Complaints of ocular pain were found to be associated with workplace hazards such as sunrays $(\mathrm{P}=0.001)$, heat $(\mathrm{P}<0.001)$ and smoke $(\mathrm{P}=0.047)$, Gritty sensation, tearing and photophobia were associated with sunrays ( $\mathrm{P} \leq 0.001,0.015,0.000)$. Photophobia was also associated with seawater $(\mathrm{P}=0.000)$.

\section{Anterior segment eye examination}

Anterior segment eye examination using a handheld slitlamp revealed pterygium was the most prevalent ocular surface disorder and trichiasis the least prevalent. The total number of cases (abnormalities detected) was 396 among the fishermen but 501 among the fishmongers (Figure 2).

There was association between some workplace hazards experienced by fishmongers such as sunrays $(\mathrm{P}=0.042)$ and heat $(\mathrm{P}=0.001)$ and pterygium but there was no such association between hazards and pterygium among fishermen. Multivariate logistic regression between workplace hazards indicated that exposure to heat was a very significant factor associated pterygium among fishmongers (Table 4).

\section{Internal eye examination}

Direct ophthalmoscopic examination revealed 169 posterior segment disorders among the fishermen, 66 (39.1\%) were glaucoma suspects, 53 (31.4\%) had cataract, 32 (18.9\%) had other posterior segment diseases like retinal degeneration, retinal scars and other retinal disorders, 8 (4.7\%) had

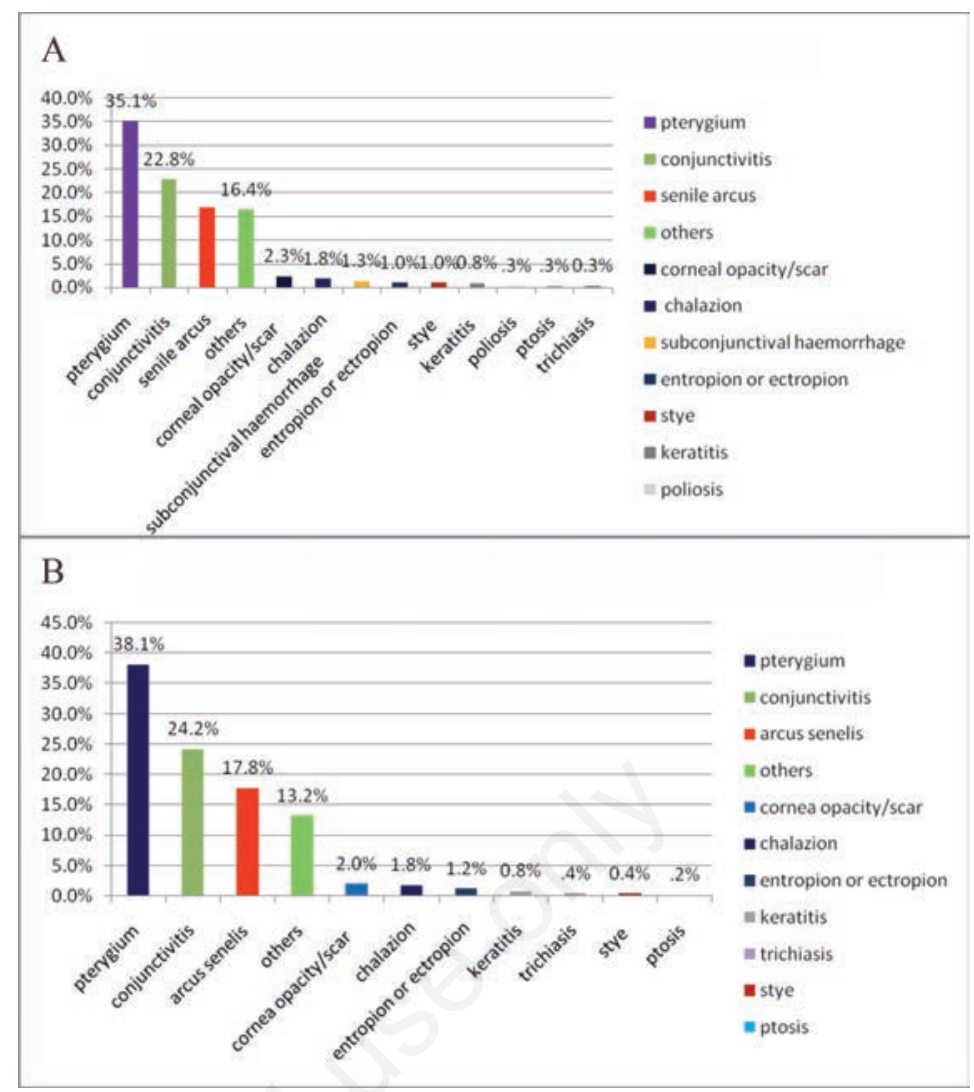

Figure 2. Prevalence of anterior segment disorder as detected upon slit lamp examination in fishermen (A) and fishmongers (B).

Table 1. Distribution of educational levels and annual income.

\begin{tabular}{|c|c|c|}
\hline Level of education/annu & Fishermen, n (\%) & Fishmongers, n (\%) \\
\hline \multicolumn{3}{|l|}{ Level of education } \\
\hline No formal education & $123(37.8)$ & $170(47.5)$ \\
\hline Elementary/primary & $110(33.8)$ & $83(23.2)$ \\
\hline Middle/junior & $87(26.8)$ & $94(26.3)$ \\
\hline Secondary/technical & $4(1.2)$ & $10(2.8)$ \\
\hline Tertiary & $1(0.3)$ & $1(0.3)$ \\
\hline \multicolumn{3}{|l|}{ Annual income ${ }^{\circ}$} \\
\hline Less than $\mathrm{GH} \varnothing 1000$ & $57(17.5)$ & $81(22.6)$ \\
\hline GHळ1000-Gh®1999 & $87(26.8)$ & $111(31.0)$ \\
\hline GHÆ2000-GH®2999 & $82(25.2$ & $90(25.1)$ \\
\hline GHÆ3000-GHФ3999 & $39(12.0$ & $49(13.7)$ \\
\hline GHÆ4000-GHळ4999 & $25(7.7)$ & $14(3.9)$ \\
\hline Greater than $\mathrm{GH} \varnothing 5000$ & $35(10.8)$ & $13(3.6)$ \\
\hline Total & $325(100.0)$ & $358(100.0)$ \\
\hline
\end{tabular}

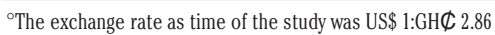

Table 2. Ocular hazards reported among fishermen and fishmongers.

\begin{tabular}{lccc} 
Havard & \multicolumn{2}{c}{ Type of occupation } & Total \\
& $\begin{array}{l}\text { Fishermen } \\
\text { N=623 (\%) }\end{array}$ & Nishmongers \\
N=717 (\%) & $357(49.8)$ & 364 \\
Smoke & $7(1.1)$ & $153(21.3)$ & 163 \\
Heat & $10(1.6)$ & $118(16.5)$ & 347 \\
Sunrays & $229(36.8)$ & $87(12)$ & 248 \\
Dust/sand & $161(25.8)$ & $2(0.2)$ & 218 \\
\hline Sea water & $216(34.7)$ &
\end{tabular}


Table 3. Ocular symptoms among fishmongers and fishermen.

\begin{tabular}{|c|c|c|c|c|c|}
\hline \multirow[t]{2}{*}{ Symptoms } & & \multicolumn{2}{|c|}{ Type of occupation } & \multirow{2}{*}{$\begin{array}{c}\text { Total } \\
\text { N }\end{array}$} & \multirow[t]{2}{*}{$P$} \\
\hline & & $\begin{array}{l}\text { Fishermen } \\
\text { N (\%) }\end{array}$ & $\begin{array}{c}\text { Fishmongers } \\
\mathrm{N}(\%)\end{array}$ & & \\
\hline Irritation & $\begin{array}{l}\text { No } \\
\text { Yes }\end{array}$ & $\begin{array}{l}188(41.1) \\
138(61.1)\end{array}$ & $\begin{array}{c}269(58.9) \\
88(38.9)\end{array}$ & $\begin{array}{l}457 \\
226\end{array}$ & $0.000^{*}$ \\
\hline Burning sensation & $\begin{array}{l}\text { No } \\
\text { Yes }\end{array}$ & $\begin{array}{l}190(47.0) \\
136(48.7)\end{array}$ & $\begin{array}{l}214(53.0) \\
143(51.3)\end{array}$ & $\begin{array}{l}404 \\
279\end{array}$ & 0.659 \\
\hline Ocular pains & $\begin{array}{l}\text { No } \\
\text { Yes }\end{array}$ & $\begin{array}{l}164(50.3) \\
162(49.7)\end{array}$ & $\begin{array}{l}203(56.9) \\
154(43.1)\end{array}$ & $\begin{array}{l}367 \\
316\end{array}$ & 0.086 \\
\hline Blurred distance vision & $\begin{array}{l}\text { No } \\
\text { Yes }\end{array}$ & $\begin{array}{c}89(27.3) \\
273(72.7)\end{array}$ & $\begin{array}{l}140(39.2) \\
217(60.8)\end{array}$ & $\begin{array}{l}229 \\
490\end{array}$ & $0.001^{*}$ \\
\hline Blurred near vision & $\begin{array}{l}\text { No } \\
\text { Yes }\end{array}$ & $\begin{array}{c}12(3.7) \\
314(96.3)\end{array}$ & $\begin{array}{c}36(10.1) \\
321(89.9)\end{array}$ & $\begin{array}{c}48 \\
635\end{array}$ & $0.001^{*}$ \\
\hline Foreign body sensation & $\begin{array}{l}\text { No } \\
\text { Yes }\end{array}$ & $\begin{array}{c}44(13.5) \\
282(86.5)\end{array}$ & $\begin{array}{c}65(18.2) \\
292(81.8)\end{array}$ & $\begin{array}{l}109 \\
574\end{array}$ & 0.096 \\
\hline Redness & $\begin{array}{l}\text { No } \\
\text { Yes }\end{array}$ & $\begin{array}{c}32(9.8) \\
294(90.2)\end{array}$ & $\begin{array}{c}14(3.9) \\
343(96.1)\end{array}$ & $\begin{array}{c}46 \\
637\end{array}$ & $0.002 *$ \\
\hline Gritty sensation & $\begin{array}{l}\text { No } \\
\text { Yes }\end{array}$ & $\begin{array}{c}94(28.8) \\
232(71.2)\end{array}$ & $\begin{array}{l}205(57.4) \\
152(42.6)\end{array}$ & $\begin{array}{l}299 \\
384\end{array}$ & $0.000^{*}$ \\
\hline Photophobia & $\begin{array}{l}\text { No } \\
\text { Yes }\end{array}$ & $\begin{array}{l}115(35.3) \\
211(64.7)\end{array}$ & $\begin{array}{l}135(37.8) \\
222(62.2)\end{array}$ & $\begin{array}{l}250 \\
433\end{array}$ & 0.491 \\
\hline Tearing & $\begin{array}{l}\text { No } \\
\text { Yes }\end{array}$ & $\begin{array}{c}71(21.8) \\
255(78.2)\end{array}$ & $\begin{array}{l}156(43.7) \\
201(56.3)\end{array}$ & $\begin{array}{l}227 \\
456\end{array}$ & $0.000 *$ \\
\hline
\end{tabular}

retinopathies, 5 (3.0\%) had toxoplasmosis scar, 3 (1.8\%) had optic atrophy and 2 (1.2\%) had maculopathies. Fishmongers on the other hand had 213 posterior segment disorders. Ninety-nine (46.5\%) had cataract, 49 (23.0\%) were glaucoma suspects, 48 (22.5\%) had other posterior segment diseases like retinal degeneration, retinal scar and other retinal disorders, 5 (2.3\%) had retinopathies, 4 (1.9\%) had maculopathies and toxoplasmosis scar, 2 (0.9\%) had optic atrophy and posterior uveitis. No association was found between any of the workplace hazards and suspicion of glaucoma among fishermen and fishmongers, nevertheless, exposure to seawater was found to be associated with the development of cataract $(\mathrm{P}=0.022)$ among fishermen. Cataract among fishmongers was associated with exposure to heat $(\mathrm{P}=0.005)$, sunrays $(\mathrm{P}=0.035)$ and dust $(\mathrm{P}=0.002)$.

\section{Discussion}

The study employed multi-stage random sampling which was most suitable since the communities studied were diverse ( 8 coastal districts with 43 coastal towns and villages and a total of 103 landing sites) in a bid to ensure representativeness. ${ }^{21}$ The male dominance in fishing has long been documented as it is deemed as a risk prone and adventurous task reserved for the males while females are more often than not discouraged and excluded. ${ }^{22}$

Table 4. Multivariate logistic regression between workplace hazards and pterygium.

\begin{tabular}{lcccc} 
Hazards & Exp (B) & P & \multicolumn{2}{c}{$95 \%$ Cl for Exp (B) } \\
Smoke & 1431268.01 & 0.999 & 0.0 & 3.038 \\
Heat & 1.951 & $0.003^{*}$ & 1.252 & 2.166 \\
Sun rays & 1.356 & 0.203 & 0.848 & \\
Constant & 0.00 & 0.99 & & \\
\hline
\end{tabular}

CI, confidence interval.

However, fish mongering is an agricultural processing activity known to involve both males and females. ${ }^{23}$ In Africa, market systems are customarily seen as compatible with the female gender's role as housekeepers and caregivers hence the few men (1.2\%) involved in these post-harvesting activities of the fishing industry. ${ }^{24}$

A greater proportion of fisher folks were illiterates with nearly half of the fishmongers (47.5\%) having no formal education at all. Recent studies have highlighted this high proportion of illiteracy among fishing communities in Africa with Females being the most affected. This phenomenon is attributable to the remote locations, marginalization and mobility of most fishing communities affecting access to education and even health. ${ }^{25-31}$ Their reported income levels, though only one of the various indices for the determination of socioeconomic status, ${ }^{32,33}$ were generally low especially among fishmongers who were predominantly females. It is common knowledge that poverty is prevalent among artisanal fish- eries of which Ghana is no exception. ${ }^{34}$ The adult population dominating the fishing industry presupposes that they are in their active age and need to earn to keep their homes. The arduous nature of the work also favors the active working population.

Due to the ubiquity of hazards in the fishing industry, fishing has been tagged as one of the most dangerous occupations in the world. ${ }^{35-37}$ At the same time, those involved in the processing of the fish are also not spared. The top three most common hazards among the fishermen were sunlight, seawater and dust/sand. These have been reported as major eye health risks among fishermen. ${ }^{38,39}$ Half of the reports from the fishmongers identified exposure to smoke as the single most important ocular hazard at their workplace due the use of biofuel (i.e. fire wood). ${ }^{40}$ Excessive heat was also found to be a worrisome hazard among fishmongers. The most prevalent complaint of ocular irritation was found to be associated with exposure to hazards such as smoke, heat, dust/sand and seawater. ${ }^{39-41}$ Other ocular com- 
plaints associated with workplace hazards were ocular pain, gritty sensation, photophobia and tearing which are mostly symptoms of conjunctivitis. ${ }^{42}$ Conjunctivitis was the second most prevalent ocular surface disease after pterygium. Pterygium was the most prevalent ocular surface disorder and was found to be associated with exposure to smoke and heat which are the two most common hazards encountered by fishmongers relative to fishermen. Fishmongers, most of whom are predominantly women, are frequently exposed to biofuels, mainly firewood and charcoal, which have been implicated in adverse consequences to the human eye. ${ }^{40,43}$ The continuous use of biofuel in poor communities such as fishing communities has been observed despite its decline in use on the global scene. ${ }^{44,45}$ Multivariate logistic regression indicated heat as the single most important predictor of developing pterygium $(\mathrm{P}=0.003)$. Other studies elsewhere have indicated a high prevalence of pterygium among agricultural workers due to exposure to heat. The linkage between heat and the pathogenesis of pterygium has been predicted previously. ${ }^{40,46}$

The association between cataract and some workplace hazards in the fisheries sector was implied but has been difficult to establish. Epidemiologists were unable to establish a simple realistic causal model for cataract because each risk factor could be a component cause. ${ }^{47}$ The multiple risk factors of the workplace environment including heat, sunrays, and dust/sand may wholly or partly be involved in the pathogenesis of age-related cataract commonly found among fishmongers. ${ }^{41,48}$ The seawater is said to be a good reflector of sunlight and may be indirectly involved in causing cataract among fishermen. ${ }^{38}$ This study highlights the fact that the continuous engagement in fishing and post harvest activities as an occupation exposes workers to potential risks which have implications for their eye health. ${ }^{49}$ It is worthy to note that several of these risk factors are manageable through the use of protective eye wears, photoprotective lenses, and re-orientation of fishers and fishmongers on modern fish processing methods. It is therefore recommended that these fishers and fishmongers be educated on safety practices and provision of first aid kits and adequate training be implemented by stakeholders in the fisheries industry.

\section{Conclusions}

In conclusion, this study found some association between workplace environments and ocular disorders in the fishing industry of Ghana. These associations are of worthy note in the context of public health intervention.

\section{References}

1. Symile MA. Perilous catch: the history of commercial fishing. Dublin: The History press Ireland; 2015.

2. FA0. The state of the World Fisheries and Aquaculture. Rome: Food and Agriculture Organization; 2000.

3. Eliasen S, Sverdrup-Jensen S, Holm P, Johnsen JP. Nordic experience of fisheries management seen in relation to the reform of the EU Common Fisheries Policy. TemaNord 2009;2009:579.

4. El-Saadawy ME, Soliman NE, El-Tayeb IM, Hammouda MA. Some occupational health hazards among fishermen in Alexandria city. Gaziantep Med J 2014; 20:71-8.

5. Kaerlev L, Jensen A, Nielsen PS, et al F. Hospital contacts for injuries and musculoskeletal diseases among seamen and fishermen: a population-based cohort study. BMC Musc Dis 2008;9:8.

6. Endresen NE. Injuries and diseases among commercial fishermen in the Northeast Atlantic and Barents Sea. Data from the Royal Norwegian Coast Guard. Int Arch Occ Environ Health 2002;76:241-5.

7. Alfaro DV, Jablon EP, Rodriguez FM, et al. Fishing-related ocular trauma. Am J Ophthalmol 2005;139:488-92.

8. Meltzoff SK, LiPuma ES. A Japanese fishing joint venture: worker experience and national development in the Solomon Islands. Manila: International Centre for Living Aquatic Resource Management; 1983.

9. Bank of Ghana. The fishing sub sector and Ghana's economy, 2008. Available from: www.bog.gov.gh

10. Ghana Statistical Service. Provisional gross domestic product 2013. Available from: www.statsghana.gov.gh

11. Britwum A0. The gendered dynamics of production relations in Ghanaian coastal fishing. Ferminist Africa 2009;12:69-85.

12. Ministry of food and Agriculture. Fisheries 2013. Available at http://www.fao.org/fishery/facp/GHA/en

13. Armah AK, Nunoo FKE, Koranteng KA. Critical issues that make reconciling fisheries with conservation an uphill task in the coastal zone of Ghana. Bethesda, MD: American Fisheries Society Symposium; 2007.

14. Amador K, Bannerman P, Quartey R, Ashong R. Ghana canoe frame survey. Marine Fisheries Research Division. Accra: Ministry of Fisheries; 2006.

15. Odotei I. The artisanal marine fishing industry in Ghana: a historical overview. Legon: Institute of African Studies,
University of Ghana; 2002.

16. ILO. ILO standards-related activities in the area of occupational safety and health. Report VI, International Labour Conference, 91st Session, 2003a. Available from: http://www.ilo.org/public/ english/protection/safework/integrap/survi ndex.htm

17. Greenberg MI, Hamilton RJ, Philips DS, McClouskey GJ. Occupational, industrial and environmental toxicology. 2nd Ed. Maryland Heights: Mosby; 2003.

18. Ghana Statistical Service. 2010 Population and Housing Census (PHC), 2012. Accra: Ghana Statistical Service; 2012.

19. Ministry of Food and Agriculture. Fisheries subsector CR, 2012. Accra: Ministry of Food and Agriculture; 2012.

20. Glenn D. Determining sample size. Sampling the evidence of extension program impact, PEOD-5, 1992. Available from: http://www.edis.ifas.ufl.edu/pd006

21. Hardon A, Hodgkin C, Fresle D. How to investigate the use of medicines by consumers. Amsterdam: University of Amsterdam; 2004.

22. FA0, WorldFish Center and World Bank. Small-scale capture fisheries. A global overview with emphasis on developing countries: a preliminary report of the Big Numbers Project. Rome \& Penang: FAO and WorldFish Center; 2008.

23. Duncan BA. Women in agriculture in Ghana. 2nd ed. Bonn: Friedrich Ebert Foundation; 2004.

24. Walker BLE. Sisterhood and seine-nets: engendering development and conservation in Ghana's marine fishery. Prof Geogr 2001;53:160-77.

25. Allison EH. Linking national fisheries policy to livelihoods on the shores of Lake Kyoga, Uganda. Norwich: Overseas Development Group (ODG), University of East Anglia; 2003.

26. Grellier R, Tanzarn N, Lamberts D, Howard C. The impact of hiv/aids on fishing communities in Uganda. London: Marine Resources Assessment Group (M RAG) and Options; 2004.

27. Keizire BB. Policy and planning processes for responding to hiv/aids in fishing communities in Uganda. In: Responding to HIV and AIDS in the Fishery Sector in Africa. Proceedings of the International Workshop held in Lusaka, Zambia, Cairo: WorldFish Centre 2006:34-40.

28. Meinert L. Sweet and bitter places: the politics of school children's orientation in rural Uganda. In: KF Olwig and E Gulløv (Eds.) Children's places: cross cultural perspectives. London: Routledge; 2003.

29. Ray R. The determinants of child labour and child schooling in Ghana. J Afr Econ 2003;11:561-90. 
30. Ansell N. Children, youth and development. Abingdon and New York: Routledge; 2005.

31. Lewin KM. Improving access, equity and transitions in education. Creating a research agenda. CREATE Pathways to Access. Research Monograph 1. Brighton: University of Sussex; 2007.

32. Bene C, Friend RM. Water, poverty and inland fisheries: lessons from Africa and Asia. Water Int 2009:34:47-61.

33. Bene C, Friend RM. Poverty in small-scale fisheries: old issue, new analysis. Prog Dev Stud 2011;11:119-44.

34. Asiedu B, Nunoo FKE, Ofori-Danson PK, et al. Poverty measurements in small-scale fisheries of Ghana: a step towards poverty eradication. Curr Res J Soc Sci 2013;5:7590.

35. El-Saadawy M, Soliman N, El-Tayeb IMM, Hammouda MA. Some occupational health hazards among fishermen in Alexandria city. Gaziantep Med J 2014;20:71-8.

36. Rodrigues DE, Kiran U. A pilot study on knowledge \& practice regarding prevention of occupational hazards and attitude towards utilisation of safety measures among fishermen working at a selected harbor. NUJHS 2013;3:3.

37. Le bouar G, Chauvin C. An analysis of the risk in the French sea fishing industry. Example of the dockside accident risk. Int Marit Health 2006;57:103-13.

38. National Institute for Occupational Safety and Health. Surveillance and prevention of occupational injuries in Alaska: a decade of progress 1990-1999, 2002. Available from: http://www.cdc.gov/niosh/docs/2002115/pdfs/2002-115.pdf

39. Burke WA, Griffith DC, Scott CM, Howell ER. Skin problems related to the occupation of commercial fishing in North Carolina. N C Med J 2006;67:260-5.

40. Saha A, Kulkarni PK, Shah A, et al. Ocular morbidity and fuel use: an experience from India. Occup Environ Med 2005;62:66-9.

41. Oriowo OM, Chou BR, Cullen AP. Eye exposure to optical radiation in the glassblowing industry: an investigation in Southern Ontario. Can J Public Health 2000;91:4714.

42. American Optometric Association. Conjunctivitis. St. Louis, M0: American
Optometric Association; 2014.

43. Bruce N, Perez-Padilla R, Albalak R. Indoor air pollution in developing countries: a major environmental and public health challenge. B World Health Organ 2000;78:9.

44. World Resources Institute, UNEP, UNDP, World Bank. 1998-99 World Resources: a guide to the global environment. Oxford: Oxford University Press; 1998.

45. World Health Organization. Health and environment in sustainable development, WH0/EHG/97.8. Geneva: World Health Organization; 1997.

46. Rohatgi S. Pterygium: an epidemological study in India. Int $\mathrm{J}$ Healthcare Biomed Res 2013;4:297-301.

47. Rothman KJ. Causes. Am J Epidemiol 1976;104:587-92.

48. Gritz DC. Can cataracts be prevented? B World Health Organ 2001;79:260-1.

49. Olaoye JO, Odebiyi OC, Abimbola OT. Occupational hazards and injuries associated with fish processing in Nigeria. $\mathrm{J}$ Aquat Sci 2015;3:1-5. 